\title{
KONSERVATISME PENDIDIKAN ISLAM
}

\author{
Eko Sumadi \\ Program Doktor Pascasarjana UIN Sunan Kalijaga Yogyakarta \\ sumadieko@gmail.com
}

\begin{abstract}
This paper begins the discussion by examining the genealogy of al-Ghazali's thinking, then discussing ideas about his education, to attract its relevance to the current practice of moral education. There are several important points that are the result of this discussion; First, that al-Ghazali's intellectual journey in the search of truth is a very dynamic intellectual dialectic, although in the end, he overrides the ability of reason in seeking the ultimate truth, he has really optimized the role of reason by placing it in a very special position. Second, for al-Ghazali that the estuary of all educational activities is to get closer to Allah. Thus, among the reasons that made al-Ghazali identified as a conservative goalkeeper. Third, however many criticisms of al-Ghazali's concept of education, many of his ideas are still relevant today, especially in matters of character building and moral education.
\end{abstract}

Key words: Al-Ghazali, Conservatism, and Moral Education

\begin{abstract}
Abstrak
Makalah ini memulai diskusi dengan memeriksa silsilah pemikiran al-Ghazali, kemudian membahas ide-ide tentang pendidikannya, untuk menarik relevansinya dengan praktik pendidikan moral saat ini. Ada beberapa poin penting yang merupakan hasil diskusi ini; Pertama, bahwa perjalanan intelektual al-Ghazali dalam pencarian kebenaran adalah dialektika intelektual yang sangat dinamis, meskipun pada akhirnya, ia mengesampingkan kemampuan nalar dalam mencari kebenaran tertinggi, ia telah benar-benar mengoptimalkan peran nalar dengan menempatkannya dalam sebuah posisi yang sangat istimewa. Kedua, bagi alGhazali bahwa muara dari semua kegiatan pendidikan adalah untuk lebih dekat kepada Allah. Dengan demikian, di antara alasan itulah yang menjadikan alGhazali diidentifikasi sebagai penjaga gawang yang konservatif. Ketiga, betapapun banyaknya kritik terhadap konsep pendidikan al-Ghazali, banyak gagasannya masih relevan hingga hari ini, terutama dalam hal pembangunan karakter dan pendidikan moral.
\end{abstract}

Kata kunci: Al-Ghazali, Konservatisme, dan Pendidikan Moral 


\section{A. PENDAhuluan}

Konservatif

(al-Muhafidz) umumnya didefinisikan sebagai kolot; bersikap mempertahankan keadaan, kebiasaan, dan tradisi yang telah berlaku. ${ }^{1}$ Istilah itulah yang disematkan oleh Muhammad Jawwad Ridha untuk menggambarkan pemikiran al-Ghazali, Nasiruddin alThusi, Ibnu Jama'ah, Ibnu Sahnun, Ibnu Hajar al-Haitami, dan al-Qabisi. ${ }^{2}$ Dalam pemikiran pendidikan Islam, aliran konservatif dibedakan dari aliran rasional-religius, yang menempatkan akal diposisi istimewa dalam pergulatan ilmu pengetahuan dan aliran pragmatis-instrumental yang lebih realistis dalam merespon tantangan zaman, sehingga kesan negatif yang muncul, tatkala mendengar istilah konservatif (kolot), yang secara langsung juga menunjuk pada pribadi dan pemikiran tokoh-tokoh yang telah disebut.

Citra negatif tersebut semakin menguat dengan adanya pandangan umum bahwa kemenangan madzab tradisionalis (sunni) atas mu'tazilah sebagai madzhab negara,pada masa pemerintahan khalifah al-Mutawakkil dinasti Abbasiyah, sebagai penyebab awal kemunduran peradaban Islam. ${ }^{3}$ Lembaga-lembaga pendidikan cenderung hanya mengajarkan ilmu-

\footnotetext{
${ }^{1}$ https://kbbi.web.id/konservatif, diunduh tanggal 28 September 2018.

${ }^{2}$ Muhammad Jawwad Ridla, Tiga Aliran Utama Teori Pendidikan Islam (Yogyakarta: PT Tiara Wacana, 2002), h.75.

${ }^{3}$ George A. Makdisi, Cita Humanisme Islam (Jakarta: PT Ikrar Mandiri Abadi, 2005), h. 25-40.
}

ilmu yang bersifat tafaqquh fiddin, sedangkan ilmu-ilmu di luar itu (ilmu sosial dan ilmu alam) tidak pernah diperhatikan bahkan dibuang dari kurikulum madrasah. ${ }^{4}$ Dalam hal ini alGhazali,menjadi bagian dari ulama madzhab tradisionalis yang pernah menjabat sebagai Rektor di madrasah Nidzamiyah, karena begitu besarnya pengaruh al-Ghazali di kalangan sunni (tradisionalis), maka sunni pun identik dengan madzhab konservatif.

artikel ini tidak bermaksud mengunggulkan aliran satu dengan yang lainnya, tidak pula ingin membela al-Ghazali dan kawan-kawannya atas tuduhan konservatif Muhammad Jawwad Ridha, karena setiap ideologi (aliran/madzhab) merefleksikan pandangan dunianya yang berbeda antara satu dengan yang lainnya. Setiap pandangan dunia dipengaruhi oleh kepercayaan epistemologinya, ${ }^{5}$ seperti dalam struktur ilmu, bahwa setiap teori (ilmu) pendidikan merupakan refleksi dari kepercayaan filsafatnya, dan setiap teori pendidikan yang terilhami dari pandangan filosofis yang diyakininya akan berkonsekuensi pada pola dan cara yang berbeda dalam menjalankan aktifitas pendidikan. ${ }^{6}$

artikel ini sekedar ingin melihat lebih dekat sosok al-Ghazali dan

${ }^{4}$ Charles Michael Stanton, Pendidikan Tinggi Dalam Islam, ter. Afandi, Hasan Asari (Jakarta: Logos Publishing House, 1994), h. viii-ix.

${ }^{5}$ Murtadha Muthahhari, Pengantar Epistemologi Islam (Jakarta: Sadra Press, 2010), h. 5-6.

${ }^{6}$ George R. Knight, Filsafat Pendidikan (Yogyakarta: Gama Media, 2007), h. 144 . 
pemikirannya, karena setiap ide lahir dalam konteks historisnya dan sekaligus mencoba mencari pembenaran atau bahkan bantahan atas tuduhan al-Ghazali sebagai dedengkot aliran pendidikan konservatif oleh Jawwad Ridho, maka pertanyaan yang akan dijawab dalam paper ini ialah bagaimana genealogi pemikiran alGhazali, bagaimana pemikirannya tenang pendidikan dan bagaimana kontekstualisasi

pendidikannya dengan pendidikan akhlak saat ini.

\section{B. SEKILAS TENTANG PRIBADI AL-GHAZALI}

Agar lebih mudah memahami idenya, penting kiranya terlebih dahulu mengenal pribadinya. Nama aslinya Abu Hamid Muhammad bin Muhammad al-Ghazali lahir di Thus. ${ }^{7}$ Sebuah kota di Khurasan, Persia yang waktu itu merupakan salah satu pusat ilmu pengetahuan di dunia Islam, ${ }^{8}$ dari seorang penenun wool sehingga dijuluki al-Ghazali, ${ }^{9}$ pada 450 H/1058 M. Di kota kelahirannya (Thus) itulah al-Ghazali belajar berbagai ilmu pengetahuan, baru kemudian ke Jurjan untuk memperdalam bidang fiqh dengan bimbingan Abu Nasr alIsmaili. ${ }^{10}$

Di usia 20 tahun ia melanjutkan studinya ke Naisabur, pada saat Imam

\footnotetext{
${ }^{7}$ Seyyed Hossein Nasr dkk, Ensiklopedi Tematis Filsafat Islam (Bandung: Mizan, 2003), h.321.

${ }^{8}$ Tim Penyusun, Ensiklopedia Islam, 4 (Jakarta: Van Hoeve Letiar Baru, 1997), h. 25.

${ }^{9}$ A. Khudori Soleh, Wacana Baru Filsafat Islam (Yogyakarta: Pustaka Pelajar, 2012), h. 80.

${ }^{10}$ Ibid.
}

Haramain, al-Juwaini menjabat sebagai kepala madrasah Nidzamiyyah. Di situlah al-Ghazali belajar fiqih, usul fiqh, manthiq, dan kalam, hingga kematian al-Juwaini. Berlanjut pada tahun $478 \mathrm{H}$, al-Ghazali pergi ke Mu'askar dan diangkat menjadi tenaga pengajar di madrasah Nidzamiyah di Baghdad pada tahun $484 \mathrm{H}$. Di tempat inilah al-Ghazali mencapai puncak prestisius dalam karir keilmuannya, sehingga kuliahnya dihadiri oleh tiga ratus ulama terkemuka di zamannya. ${ }^{11}$

Banyak atribut yang melekat pada pribadi al-Ghazali, sebagai filsuf, sufi, fuqoha', hujjatul Islam sekaligus seorang pemimpin yang menonjol di zamannya. Al-Ghazali tergolong ulama yang berpegang teguh pada al-Qur'an dan as-Sunnah, taat menjalankan agama dan menghiasi dirinya dengan perilaku tasawuf. ${ }^{12} \mathrm{Al}-\mathrm{Ghazali}$ juga mempelajari berbagai pengetahuan seperti ilmu kalam, filsafat, fiqih, dan tasawuf.Bahkania juga pernah masuk diberbagai aliran seperti, Bathniyah, Dzahiriah,serta dekat dengan kaum zindiq dan atheis, meskipun pada akhirnya ia lebih tertarik pada fiqih dan tasawuf.

Hal tersebut didasarkan pada perkataan al-Ghazali sendiri:

"Saya menyelami doktrin kaum bathniyah karena tertarik menyingkap kedalaman aspek batinnya. Saya mendalami doktrin dzahiriyah untuk mengukur kemampuan pandangannya yang berdasar aspek lahir. Saya tidak mengarungi filsafat, kacuali karena

\footnotetext{
${ }^{11}$ Al-Ghazali, Tahafut Al-Falasifah (Bandung: Penerbit MARJA, 2012), h.17.

${ }^{12}$ Abuddin Nata, Pemikiran Para Tokoh Pendidikan Islam (Jakarta: Raja Grafindo Persada, 2000), h.14
} 
saya ingin mengetahui hakikat kebenaran filosifinya. Saya merambah dunia theologi (kalam) karena ingin tahu puncak kacanggihan logika dan pola-pola debat yang digunakannya. Saya memasuki dunia tasawuf karena ingin tahu rahasia kesufian. Saya mencermati para ahli ibadah karena ingin melihat apa yang ia dapat dari ibadah yang mereka lakukan. Saya mengenali orang-orang zindiq dan atheis untuk meneliti lebih jauh tentang sesuatu yang ada di balik keyakinan mereka supaya bisa mengetahui faktor dan sebab apa yang menggiring mereka padakeyakinan dan sikap tersebut. Rasa haus terhadap pengetahuan tentang hakikat persoalan adalah minat dan kebiasaan saya sejak muda. Ia merupakan karakter dan fitrah yang dianugerahkan oleh Allah dalam kepribadian saya, bukan atas kehendak dan rekayasa saya sendiri, sehinnga saya bisa melepaskan diri dari kungkungan sifat taqlid dan mampu menghancurkan warisan kayakinan lama semenjak masih belia."13

\section{DINAMIKA PEMIKIRAN AL- GHAZALI}

Al-Ghazali hidup pada saat dunia Islam diliputi silang pendapat dan pertentangan. Masing-masing kelompok bangga dengan ideologinya masing-masing. Namun al-Ghazali sangat selektif dan kritis terhadap semua golongan. Tidak akan ia mengikuti satu golongan, tanpa melakukan penelitian mendalam terhadap golongan yang akan diikutinya. Peran pertama dapat digambarkan bahwa al-Ghazali berhadapan dengan banyak aliran dan

h. 20 .

${ }^{13} \mathrm{Al}-$ Ghazali, Tahafut Al-Falasifah, kelompok serta pendapat yang saling bertentangan. Karena itu, ia ingin menjaring kebenaran dari berbagai pendapat itu, lalu mementahkan hegemoni pemikiran tradisional yang diwarisi secara turun-temurun serta mencampakkan kesakralannya. Ia pun mulai melakukan kajian untuk menemukan kebenaran dari berbagai kelompok tersebut. ${ }^{14}$

Al-Ghazali melakukan

investigasi dalam mencari kebenarannya dengan menggunakan perangkat akal, indera, makna alQur'an dan Hadits, serta disiplindisiplin lain untuk kepentingan pembuktian yang banyak dikenal pada masa itu. Al-Ghazali mulai mengkaji dalil-dalil yang saling bertentangan (yang sering dipakai sebagai pembenar antar golongan) tersebut di bawah cahaya al-'ilm al-yaqini (pengetahuan yang diyakini kebenarannya), sebagai pengetahuan yang didambakan yaitu pengetahuan yang diyakini mampu menyingkap segala objek pengetahuan sehingga tidak lagi menyisakan keraguan, tidak lagi mengusung kemungkinan kesalahan, dan tidak memberikan ruang dalam jiwa untuk mengetahui berdasarkan perkiraan, jika seperti itu pengetahuan yang benar versi al-Ghazali, maka standar yang benar adalah standar yang mengantar pada kebenaran tersebut. Jelas bahwa selama keinginan seperti ini terus menguat dan tetap menuntut model kepercayaan dan kekokohan yang tinggi, ia harus menetapkan akal dan indera saja dengan membuang

${ }^{14}$ Ibid., h.18-36. 
perangkat lainnya, ${ }^{15}$ selain itu Imam Ghazali banyak membahas cara-cara mendekatkan diri kepada Allah ${ }^{16}$.

Hanya saja, al-Ghazali belum merasa puas terhadap akal dan indera tanpa melakukan pengujian yang seksama untuk mencari kejelasan apakah keduannya dapat mewujudkan keyakinan yang ia harapkan ternyata akal dan indera pun tidak mampu mengantarkan pada al-ilm al-yaqini (pengetahuan yang didambakan oleh al-Ghazali).

Inilah krisis keraguan dahsyat yang dilukiskan sebagai peran kedua, dalam krisis tersebut al-Ghazali tidak memiliki kepercayaan apa pun. Di hadapannya tidak ada yang valid, baik dalil maupun yang ditunjukkan oleh dalil (madlul). Hingga akhirnya turunlah rahmat Allah kepadanya. Pertama, ia diberi kemampuan untuk memperoleh dalil, kedua, ia diantar menuju kelompok yang benar di bawah cahaya petunjuk-Nya, cahaya itulah kunci kebanyakan pengetahuan (ma'rifah). ${ }^{17}$

Setelah Allah mengobati alGhazali dari penyakit keraguan yang dialaminya, kemudian al-Ghazali dapat membatasi golongan-golongan pencari kebenaran menjadi empat kelompok:

1. Para teolog (mutakallumin), yaitu kelompok yang mengaku sebagai rasionalis (ahl ar-ra'yi wa annazhar).

${ }^{15}$ Ibid.

16 M. Ihsan Dacholfany, Pendidikan Tasawuf di Pondok Modern darussalam Gontor, Jurnal Nizham, Vol.4, No.02 JuliDesember 2015, h. 31

${ }^{17}$ Ibid.
2. Penganut kebatianan (bathiniyah), kelompok yang mengklaim diri sebagai pemegang pengajaan (ta'lim) dan kelompok yang mengkhususkan diri pada adopsi ajaran imam yang suci (al-imam al-ma'sum).

3. Kelompok filosof, yaitu kelompok orang-orang yang mengklaim diri sebagai pemilik logika dan penalaran demonstratif.

4. Golongan sufi, yaitu mereka yang mengaku kelompok elit yang terhormat (khawash al-hadhrah) dan kelompok yang bisa menyaksikan dan menyingkap kebenaran hakiki (ahl almusyahadah wa al-mukhasyafah).

Al-Ghazali masuk dan menyelami ke dalam semua golongan tersebut, untuk mencari kebenaran yang hakiki (kebenaran yang tidak bisa diragukan lagi) tetapi nyaris tidak menemukannya kecuali pada golongan yang terakhir (golongan para sufi). Di sinilah al-Ghazali mendapatkan pengetahuan yang memuaskan jiwanya serta terjamin keamanannya dari kesalahan.

\section{GAGASAN AL-GHAZALI TENTANG PENDIDIKAN}

Konsep pendidikan al-Ghazali tertuang dalam dua karyanya, ihya' ulum al-din dan ayyuh al-walad. Hal penting yang harus dicermati dalam kedua karya tersebut adalah bahwa keduanya ditulis setelah al-Ghazali sembuh dari krisis kejiwaan. Kenyataan demikian mengakibatkan pemikiran pendidikan al-Ghazali 
mengedepankan pembersihan jiwa dari noda-noda akhlak dan sifat tercela.

$$
\text { Perbincangan al-Ghazali }
$$

mengenai pendidikan yang terdapat dalam kitab ihya' berkisar dalam 3 hal pokok: ${ }^{18}$

\section{Pembicaraan tentang keutamaan ilmu pengetahuan}

Dalam hal ini, al-Ghazali memaparkan argumen-argumen baik dari dalil naqli maupun dalil aqli. Dalil naqlinya sama halnya dengan tokohtokoh ahli pendidikan yang lain, yaitu mengambil dari al-Qur'an, al-Hadits dan pendapat para pakar yang sama, sedangkan dalil aqlinya banyak berbeda dengan para ahli pendidikan yang lain. Argumen-argumen aqlinya berorientasi pada tujuan tunggal berupa pengarahan individu menuju kedekatan diri dengan Allah.

\section{Pengklasifikasian ilmu-ilmu yang termasuk dalam program kurikuler.}

\section{Mengenai}

klasifikasi

pengetahuan, al-Ghazali membaginya menjadi: Pertama, berdasarkan jenisnya: ilmu-ilmu pokok ( $u s h u l$ ) yang mencakup al-Qur'an dan Hadits, ilmuilmu furu' yang mencakup fiqih, ilmuilmu pengantar (bantu) yang mencakup ilmu bahasa, dan ilmu-ilmu pelengkap (mutammimat) seperti al-qiraat dan tafsir. Kedua, berdasarkan nilainya: ilmu-ilmu yang terpuji seluruhnya yaitu ilmu-ilmu agama (karena ilmu-ilmu ini mensucikan jiwa dan mendekatkan diri kepada Allah), ilmu-ilmu yang tercela

\footnotetext{
${ }^{18}$ Ibid., h.120.
}

seluruhnya yaitu ilmu-ilmu yang tidak bisa diharapkan manfaatnya di dunia dan akhirat, seperti ilmu-ilmu sihir, astrologi atau perbintangan, dan ilmuilmu yang kalau dipelajari sedikit termasuk ilmu terpuji tetapi kalau dipelajari secara mendalam menjadi ilmu tercela, karena dapat membawa kekufuran seperti ilmu filsafat. Ketiga, berdasarkan kepentingannya, yaitu: ilmu fardlu 'ain, (ilmu tentang cara mengamalkan amalan yang wajib) seperti shalat, puasa, zakat, dan sebagainya. Ilmu fardlu kifayah yaitu setiap ilmu yang tak dapat ditinggalkan dalam kehidupan masyarakat. Contohnya yaitu ilmu kedokteran, keterampilan dan ilmu hitung. ${ }^{19}$

\section{Kode etik bagi pendidik (guru) dan peserta didik.}

Murid memiliki beberapa kewajiban, antara lain: Pertama, memprioritaskan penyucian diri dari akhlak yang tercela dan sifat buruk, sebab ilmu itu bentuk peribadahan hati, shalat rohani dan dan pendekatan batin kepada Allah; Kedua, peserta didik wajib menjaga diri dari kesibukankesibukan duniawi dan seyogyanya berkelana jauh dari tempat tinggalnya; Ketiga, tidak membusungkan dada terhadap orang alim (guru), melainkan bersedia patuh dalam segala urusan dan bersedia mendengarkan nasihatnya; Keempat, bagi penuntut ilmu pemula sebaiknya menghindarkan diri dari mengkaji variasi pemikiran dan tokoh,

\footnotetext{
${ }^{19}$ Syamsul Kurniawan and Erwin Mahrus, Jejak Pemikiran Tokoh Pendidikan Islam (Jogjakarta: AR-RUZZ MEDIA, 2011), h.91-92.
} 
baik menyangkut ilmu-ilmu duniawi maupun ilmu-ilmu ukhrawi; Kelima, penuntut ilmu tidak mengabaikan suatu disiplin ilmu apapun yang terpuji, melainkan bersedia mempelajarinya hingga tau akan orientasi dari disiplin ilmu yang dimaksud; Keenam, penuntut ilmu dalam usaha mendalami suatu disiplin ilmu tidak dilakukan secara sekaligus, akan tetapi perlu bertahap dan memprioritaskan yang terpenting; Ketujuh, penuntut ilmu tidak melangkah mendalami tahap ilmu berikutnya sehingg ia benar-benar menguasai tahap ilmu sebelumnya; Kedelapan, penuntut ilmu hendaknya mengatahui faktor-faktor yang menyebabkan dapat memperoleh ilmu yang paling mulia; Kesembilan, tujuan belajar penuntut ilmu adalah pembersihan batin dan menghiasinya dengan keutamaan serta pedekatan diri kepada Allah serta meningkatkan maqom spiritualnya; Kesepuluh, penuntut ilmu mengetahui relasi ilmuilmu yang dikajinya dengan orientasi yang dituju, sehingga dapat memilah dan memilih ilmu mana yang harus diprioritaskan. ${ }^{20}$

Sementara tentang kewajiban seorang guru, al-Ghazali berpandangan sangat idealistik.Baginya, guru adalah orang yang berilmu dan beramal saleh. Orang seperti ini adalah gambaran orang yang terhormat. Dari sini alGhazali menekankan perlunya keterpaduan antara ilmu dan amal. Ia menyerupakan guru sejati dengan matahari yang menyinari sekelilingnya,

\footnotetext{
${ }^{20}$ Muhammad Jawwad Ridla, Tiga Aliran Utama Teori Pendidikan Islam, h.124128.
}

dan minyak wangi yang membuat harum di sekitarnya. Berangkat dari persepsi idealistik profesi guru tersebut, al-Ghazali menandaskan bahwa orang yang sibuk mengajar merupakan orang yang bergelut dengan sesuatu yang penting, sehingga ia perlu menjaga etiket dan kode etik profesinya. $^{21}$

Kode etik dan tugas profesi yang harus dipatuhi oleh guru (pendidik) meliputi delapan hal: Pertama, menyayangi peserta didiknya, bahkan memperlakukan mereka seperti perlakuan dan kasih sayang guru kepada anaknya sendiri; Kedua, guru bersedia sungguh-sungguh mengikuti tuntutan Rasulullah, sehingga ia tidak mengajar untuk mencari upah atu untuk mendapatkan penghargaan dan tanda jasa; Ketiga, guru tidak boleh mengabaikan tugas memberi nasihat kepada peserta didiknya; Keempat, termasuk profesionalisme guru, adalah mencegah peserta didik jatuh terjerembab kedalam akhlak tercela melalui cara sepersuasif mungkin dan melalui cara penuh kasih sayang, tidak dengan cara mencemooh dan kasar; Kelima, kepakaran guru dalam spesialisasi keilmuan tertentu tidak menyebabkan memandang remeh disiplin keilmuanlainnya, semisal guru yang pakar dalam ilmu bahasa, tidak menganggap remeh ilmu fiqih dan sebagainya; Keenam, guru menyampaikan materi pengajarannya sesuai dengan tingkat pemahaman peserta didiknya; Ketujuh, terhadap peserta didik yang berkemampuan 
rendah, guru menyampaikan materi yang jelas, kongkrit dan sesuai tingkat kemampuan peserta didik dalam mencernanya; Kedelapan, guru mau mengamalkan ilmunya, sehingga yang ada adalah menyatukannya ucapan dan tindakan. $^{22}$

Adapun kitab ayyuh al-walad berisi 22 nasehat yang ditujukan kepada murid-muridnya agar mereka lebih mengorientasikan berbagai hal yang harus dilaksanakannyadalam proses belajar, sehingga apa yang menjadi tujuannya dapat tercapai. ${ }^{23}$ Kitab Ayyuh al-Walad merupakan kitab yang berupa lembaran-lembaran pesan Imam AlGhazali kepada muridnya. Pesan tersebut beliau tulis dalam sebuah kitab untuk memberikan jawaban atas surat muridnya yang diajukan kepadanya. Sang murid yang telah membaktikan diri dan menimba ilmu dengan tekun kepada Imam Al-Ghazali sehingga telah menguasai berbagai macam disiplin ilmu. Bahkan sang murid selalu berusaha untuk mencapai kesempurnaan jiwanya. Lantas dari sekian banyak disiplin ilmu dan telah dihabiskan umurnya untuk mempelajari dan menghimpunnya, sang murid merasa bimbang tentang ilmu mana saja yang bermanfaat dan selalu menemaninya hingga keliang lahat. Dan jika ilmu tersebut tidak bermanfaat baginya maka supaya dibuang saja. ${ }^{24}$

\footnotetext{
${ }^{22}$ Ibid., h.129-132.

${ }^{23} \mathrm{Al}$ Ghazali, Ayyuhal Walad (Kediri: Muhammad Usman, 1412).

${ }^{24}$ Al-Ghazali,

Prinsip-Prinsip

Menapaki Jalan Spiritual: Wasiat Terakhir Untuk Murid Kesayangannya (Yogyakarta: Diamond, 2010),h. 2.
}

\section{E. TUJUAN PENDIDIKAN AL- GHAZALI}

Tujuan pendidikan merupakan konsepsi yang lahir dari refleksi kepercayaan falsafahnya. Dari bagaimana al-Ghazali memandang hakikat semesta, hakikat Tuhan, hakikat manusia, hakikat pendidikan, tentang sumber pengetahuan dan validitasnya, tentang nilai, etika dan estetikanya. Juga dipengaruhi oleh konteks historisnya, di mana dan di saat al-Ghazali hidup. Baik faktor politik, soaial, ekonomi dan sebagainya. Dari refleksi mendalam terhadap berbagai faktor itulah, lahir tujuan pendidikan yang bagi alGhazali, segala aktifitas pendidikan memiliki tujuan akhir, mencapai kesempurnaan manusia yang bermuara pada pendekatan diri kepada Allah dan kesempurnaan manusia yang bermuara pada kebahagiaan dunia dan akhirat. Menurutnya, setiap manusia pasti mendambakan kebahagiaan dunia dan akhirat, oleh karena itu, kebahagiaan tersebut hanya dapat tercapai melalui ilmu dan amal. ${ }^{25}$

Memang benar bahwa alGhazali merupakan seorang ulama mazhab yang bisa dibilang sangat militan terhadap tradisi intelektual mazhab tradisionalisnya (sunni), maka jika pelabelan konservatif (kolot) didasarkan pada bagaimana pandangan dunia al-Ghazali yang teramat religiustradisionalis dinilai kurang responsif terhadap perkembangan zaman. Pandangan itu sangat berpengatuh terhadap konsepsi tujuan

${ }^{25}$ Abuddin Nata, Pemikiran Para

Tokoh Pendidikan Islam., h.43 
pendidikannya, mungkin benar adanya dan bisa diterima, namun perlu juga dicermati, bahwa konklusi-konklusi yang terakumulasi dalam pandangan filosofisnya bukanlah diperoleh dari tindakan taklid semata. Melainkan ia peroleh melalui pembacaan dan refleksi yang mendalam sesuai dengan konteksnya. Maka ketika mengacu pada yang terakhir ini, gagasan alGhazali justru sangat progresif dan bukan anti realitas, setidaknya untuk ukuran pada zamannya sehingga tuduhan konservatif dalam arti sematamata mempertahankan tradisi sekaligus menolak kemajuan, tentu tidaklah tepat dialamtkan kepadanya.

Argumentasi ini bisa dipertimbangkan jika melihat bagaimana dinamika pemikiran alGhazali dalam proses pencarian kebenaran.Dan dalam setting sosial yang bagaimana al-Ghazali hidup dan melahirkan karya-karyanya. Al-Ghazali telah menghabiskan banyak waktu untuk menyelidiki pengetahuan dan bagaimana manusia memperoleh pengetahuan itu. Ia membahas nilai sekaligus bagaimanaintelek memainkan peran dalam perolehan pengetahuan, dan bagaimana manusia bisa memperoleh pengetahuan, bahkan untuk memuliakan akal,ia menggunakan analogi tubuh menjadi seperti kerajaan, di mana hati dan pikiran adalah raja dan bagian lain dari tubuh adalah hamba raja, ${ }^{26}$ maka jika

${ }^{26}$ LatefahcAlkanderi, "Exploring Education In Islam: Al-Ghazali's Model of the Master-Pupil Relationshipapplied to Educational Relationships Within the Islamic Family" (2001), h. 93-97. tuduhan konservatif dibedakan dari aliran rasional-religius yang memposisikan akal pada posisi yang istimewa, al-Ghazali pun juga demikian, hanya saja antara akal dan hati (irfan) harus selaras.

Aristoteles, yang hidup sebelum Al-Ghazali, dan Descartes, yang hidup setelah Al-Ghazali, mereka menerima sesuatu sebagai benar hanya setelah mempertimbangkan hal itu. Jadi alGhazali tidak menerima taklid buta, segala sesuatu harus diperiksa kebenarannya. Al-Ghazali merekomendasikan untuk memeriksa kebenaran, sehingga tidak ada lagi keraguan di dalamnya. Tapi ini bukan untuk mengatakan bahwa segala sesuatu yang otomatis tidak dapat diandalkan, namun ia ingin siswa untuk meluangkan waktu untuk menyelidikidan tidak hanya berasumsi bahwa ada sesuatu tapi tidak jelas. AlGhazali menegaskan bahwa mereka yang tidak tahu kebenaran akan tinggal di kegelapan dan kesalahan. Dalam teori pengetahuan, al-Ghazaliingin memberitahu, bahwa guru perlu menyadari semua proses untuk mengetahui (peran kecerdasan, cara untuk mengetahui, proses pembelajaran untuk belajar) hubungan mereka dengan murid dalam pendidikan. ${ }^{27}$

\section{F. KURIKULUM MENURUT AL- GHAZALI}

Bagi al-Ghazali, potensi manusialah yang membentuk ragam pengetahuan. Ilmu tentang jalan menuju akhirat menjadikan rasio yang membuat manusia bisa menerima

\footnotetext{
${ }^{27}$ Ibid.
} 
amanat Allah, dengannya mendekati Tuhan. ${ }^{28} \mathrm{Al}-$ Ghazali mengklasifikasikan pengetahuan menjadi beberapa kategori. Pertama, berdasarkan jenisnya: ilmu-ilmu pokok ( $u s h u l$ ) yang mencakup al-Qur'an dan Hadits, ilmuilmu furu' yang mencakup fiqih, ilmuilmu pengantar (bantu) yang mencakup ilmu bahasa, dan ilmu-ilmu pelengkap (mutammimat) seperti al-qiraat dan tafsir. Kedua, berdasarkan nilainya: ilmu-ilmu yang terpuji seluruhnya yaitu ilmu-ilmu agama (karena ilmu-ilmu ini mensucikan jiwa dan mendekatkan diri kepada Allah), ilmu-ilmu yang tercela seluruhnya yaitu ilmu-ilmu yang tidak bisa diharapkan manfaatnya di dunia dan akhirat, seperti ilmu-ilmu sihir, astrologi atau perbintangan, dan ilmuilmu yang kalau dipelajari sedikit termasuk ilmu terpuji tetapi kalau dipelajari secara mendalam menjadi ilmu tercela, karena dapat membawa kekufuran seperti ilmu filsafat. Ketiga, berdasarkan kepentingannya, yaitu: ilmu fardlu 'ain, (ilmu tentang cara mengamalkan amalan yang wajib) seperti shalat, puasa, zakat, dan sebagainya, dan ilmu fardlu kifayah yaitu setiap ilmu yang tak dapat ditinggalkan dalam kehidupan masyarakat, contohnya yaitu ilmu kedokteran, keterampilan dan ilmu hitung. ${ }^{29}$

$\begin{array}{ccr}\text { Dari } & \text { ketiga } & \text { klasifikasi } \\ \text { pengetahuan } & \text { menurut } & \text { al-Ghazali } \\ \text { tersebut, kategori yang terakhir disebut }\end{array}$

${ }^{28}$ Muhammad Jawwad Ridla, Tiga Aliran Utama Teori Pendidikan Islam, h.77.

${ }^{29}$ Syamsul Kurniawan and Erwin Mahrus, Jejak Pemikiran Tokoh Pendidikan Islam, h. 91-92. sangat erak kaitannya dengan kurikulum yang dirumuskan oleh alGhazali. Namuan menurut penulis, perlu dilakukan penafsiran ulang terhadap kategori terakhir, yaitu ilmu fardlu 'aindan ilmu fardlu kifayah agar sesuai dengan konteks sekarang.

Menurut fiqih, hukum fardlu kifayah adalah suatu kewajiban yang tidak mengikat pada setiap individu, melainkan kewajiban yang menjadi gugur jika telah ada yang mewakilinya, dan sebaliknya jika dalam suatu daerah tidak ada satu pun yang mewakilinya maka akan berdosa seluruhnya, sehingga dalam konteks hukum fardlu kifayah, aspek keterwakilan dalam ruang lingkup tertentu yang menjadi titik tekan.

Dalam penjelasan-penjelasan yang ada tidak ada yang secara tegas memberi batasan wilayah untuk konteks hukum fardlu kifayah itu sendiri, entah itu lingkup negara, pulau, provinsi, kabupaten/kota, kecamatan, desa, atau bahkan RT. Ketika hukum ilmu yang bersifat fardlu kifayah tadi diterapkan dilingkungan RT atau desa misalnya, maka minimal tiap desa atau RT akan ada seorang dokter, ahli matematika dan ahli-ahli yang lain yang masuk dalam kategori ilmu fardlu kifayah dan tentunya akan meminimalisir adanya kesenjangan antara ilmu fardlu 'aindan ilmu fardlu kifayah, jadi semakin ruang lingkupnya dipersempit maka akan lebih baik.

\section{G. METODE PENGAJARAN AL- GHAZALI}

Salah satumetode pengajaran AlGhazali adalah menceritakan kisah 
tentang orang-orang salehs ebagai model untuk perilaku anak pada awalpendidikan informal mereka, selain itu metode pengajaran al-Ghazali adalah metode keteladanan bagi mental anak-anak, pembinaan budi pekerti, dan penanaman sifat-sifat keutamaan pada diri mereka. Menurutnya mengajar adalah pekerjaan yang paling mulia dan sekaligus sebagai tugas yang paling agung. Kiranya tidak ada lagi martabat yang lebih tinggi dari pada sebagai perantara untuk mendekatkan diri kepada Allah.

Gil'adi mencatat bahwa AlGhazali merekomendasikan pendidikan formal bagi anak-anak mulai di sekitar usia enam atau tujuh tahun, di mana orang tua perlu waktu meningkatkan pengawasan mereka, tetapi bahwa pembelajaran informal tepat untuk memulai di usia muda. ${ }^{30}$

\section{H. PROBLEM MORAL MASYARAKAT MODERN}

Moralitas (akhlak) merupakan tujuan mendasar dalam ajaran Islam. Tesis demikian setidaknya didukung dua tokoh intelektual muslim, Fazlur Rahman dan Syafi'i Ma'arif. Bagi Rahman,tujuan sentral al-Qur'an adalah untuk menciptakan sebuah tata sosial yang mantap dan hidup di muka bumi, yang adil dan diasaskan pada etika (moralitas), ${ }^{31}$ sedangkan menurut Ma'arif, Islam sangat menekankan

\footnotetext{
${ }^{30}$ LatefahcAlkanderi, Exploring Education In Islam: Al-Ghazali's Model of the Master-Pupil Relationshipapplied to Educational Relationships Within the Islamic Family, h.109-114.

${ }^{31}$ Fazlur Rahman, Tema-Tema Pokok Al Qur'an. (Bandung: Pustaka, 2000), h.56.
}

perlunya sistem ontologis untuk membina sebuah tatanan masyarakat dan peradapan yang menjadikan prinsip moral transendental menjadi asas utamanya. $^{32}$

Meski posisi moralitas atau akhlak dalam agama begitu sentral, namun dalam realitas kehidupan manusia sering terabaikan dan tersingkirkan. Orang terlalu percaya pada kemampuan manusia modern dengan seperangkat logika rasionalistik dan positivistik yang menjadi pondasi bagi bangunan pemikiran dan aksinya. Memang, diakui bahwa manusia modern telah mencatat sukses secara materi dan kaya akan ilmu pengetahuan dan teknologi, tetapi ternyata itu belum cukup memberi bekal bagi kelangsungan hidup manusia dan kemanusiaannya.

Kenakalan remaja, pembunuhan, perkosaan, seks bebas, pesta miras, narkoba, memanasnya isu SARA, fitnah dan berita-berita hoax yang begitu massifnya di berbagai media merupakan di antara contoh problem moralitas yang melanda bangsa Indonesia. Sebuah bangsa yang mengedepankan keluhuran nilai-nilai ketimuran seperti keramahan, halus budi, gotong royong, berkepribadian luhur, dan religius. Tidak selayaknya menampilkan sikap brutal, korup, arogan, emosional dan sebagainya, namun demikianlah realitasnya, maka hal yang demkian membuktikan bahwa nilai-nilai karakter, moralitas dan akhlak telah tercerabut dari lubuk hati

${ }^{32}$ A. Syafi'i Ma'arif, Membumikan Islam (Yogyakarta: Pustaka Pelajar, 1995),h. 64. 
manusia, termasuk masyarakat Indonesia, apalagi mayoritas masyarakat sekarang ini menginginkan suatu perubahan dalam semua aspek kehidupan $^{33}$.

Melihat kenyataan demikian, kemudian semua orang menengok ke arah pendidikan, terutama pendidikan agama yang dianggap sebagai institusi yang paling bertanggung jawab terhadap pembentukan moral Bangsa, meskipun, pendidikan bukanlah satusatuya faktor penyebab, melainkan terdapat banyak variabel lain yang juga dapat menyebabkan munculnya persoalan-persoalan dalam kehidupan manusia, namun tetap, pertama harus dievaluasi dan dibenahi adalah pendidikan, karena pendidikan berusaha menekankan akan pentingnya pendidikan karakter ${ }^{34}$, moral, akhlak dan lain sebagainya.

Pendapat demikian tidak sepenuhnya dapat dipersalahkan jika ditilik pada hakekat pendidikan itu sendiri,tanpa harus memaparkan puluhan definisi dari para pakar pendidikan, dapat dipahami secara jelas bahwa pendidikan harus menyentuh aspek jasmani dan rohani, fisik dan psikis, mental dan moral. Diharapkan pendidikan harus menggarap ranah kognitif, afektif dan psikomotorik secara bersamaan.

Telah nyata, bahwa sebagaimana manusia yang larut dalam modernisasi,

33 M. Ihsan Dacholfany, Konsep Masyarakat Madani Dalam Islam, Jurnal Akademika, 2012, h.28

${ }^{34}$ M. Ihsan Dacholfany, Pendidikan Tasawuf di Pondok Modern darussalam Gontor, Jurnal Nizham, Vol.4, No.02 JuliDesember 2015, h. 31, h.30

pendidikan pun ikut terseret dalam arus itu, yang ternyata gagal mengembangkan manusia seutuhnya. Dalam pemikiran dan praktreknya, saat ini pendidikan lebih dibangun di atas landasan paradigma rasionalisme, empirisme an positivisme, sebagai ciri utama paradigma ilmu pengetahuan kontemporer (modern). Hal ini telah memaksa konsep pendidikan bergeser kearah paradigma sistem pengajaran semata yang akibatnya, pengembangan spiritualitas manusia menjadi sesuatu yang asing dalam proses pendidikan bahkan dalam pendidikan Islam sekalipun. $^{35}$

Pergeseran paradigma dari pendidikan ke pengajaran tersebut dikomentari secara sarkastis oleh Arifin, bahwa paradigma demikian tidak ubahnya seperti pengajaran terhadap binatang, yakni transfer pengetahuan atau ketrampilan yang teramat mekanik. Paradigma sistem pengajaran, dalam hal demikian menempatkan pendidik dan peserta didik dalam posisi yang diametral. Anak didik diharuskan menghafal ini dan itu karena sistem pengajaran sangat mekanik, meskipun hal ini tidak jelek, tetapi di satu sisi justru mengorbankan aspek-aspek lainnya seperti penalaran dan budi pekerti. Padahal pendidikan dimaksudkan untuk mengembangkan kecakapan intelektual dan moral sekaligus.

\begin{tabular}{l} 
Melihat persoalan di atas, \\
$\begin{array}{l}\text { konsep pendidikan al-Ghazali } \\
\text { menemukan relevansinya, bahwa }\end{array}$ \\
\hline $\begin{array}{l}{ }^{35} \text { Syamsul Arifin, dkk., Spiritualisasi } \\
\text { Islam Dan Peradaban Masa Depan } \\
\text { (Yogyakarta: Sipres, 1996), h.155. }\end{array}$
\end{tabular}


pendidikan bukan sekedar transfer of knowledge, pendidikan harus mampu menyentuh hati dan kejiwaan anak didiknya, sehingga pendidikan bukan saja berorientasi pada aspek kognitif saja melainkan juga menyentuh aspek afektif dan psikomotorik sekaligus.

\section{SIMPULAN}

Hal penting yang perlu dicatat dalam perjalanan intelektual al-Ghazali dalam rangka mencari kebenaran adalah proses dialektika intelektualnya yang sangat dinamis, ia benar-benar mengoptimalkan peran akal meskipun akhirnya akal tidak mampu menemukan kebenaran yang sesungguhnya, tetapi akal bagi alGhazali berada pada posisi yang sangat istimewa.

Konsep pendidikan al-Ghazali tertuang secara jelas dalam kitab ihya' dan ayyuh al-walad. Ia mendeskripsikan pengetahuan, kebaikan pengetahuan, cara memperoleh pengetahuan, hakikat pengetahuan, sumber pengetahuan, metode, dan tujuan pendidikan serta kurikulumnya. Dengan demikian alGhazali memandang bahwa semua aktifitas tersebut muaranya adalah untuk mendekatkan diri kepada Allah.

Meskipun banyak yang mengkritik tentang relevansi konsep pendidikan al-Ghazali di era sekarang, tetapi banyak yang masih relevan, misalnya: metode pembelajarannya (metode keteladanan), dalam mengoptimalkan peran akal, dan sebagian kurikulumnya, meskipun ada beberapa hal yang sekiranya perlu ditafsirkan ulang.

\section{DAFTAR PUSTAKA}

Al Ghazali. Ayyuhal Walad. Kediri: Muhammad Usman, 1412.

Al-Ghazali. Prinsip-Prinsip Menapaki Jalan Spiritual: Wasiat Terakhir Untuk Murid Kesayangannya. Yogyakarta: Diamond, 2010.

Tahafut Al-Falasifah. Bandung: Penerbit MARJA, 2016.

Alkanderi, Latefah. "Exploring Education In Islam: AlGhazali's Model of the MasterPupil Relationshipapplied to Educational Relationships Within the Islamic Family." 2001.

Knight, George R. Filsafat Pendidikan. terj. Mahmud Arif. Yogyakarta: Gama Media, 2007.

Kurniawan, Syamsul, and Erwin Mahrus. Jejak Pemikiran Tokoh Pendidikan Islam. Jogjakarta: AR-RUZZ MEDIA, 2011.

Ma'arif, A. Syafi'i. Membumikan Islam. Yogyakarta: Pustaka Pelajar, 1995.

M. Ihsan Dacholfany, Pendidikan Tasawuf di Pondok Modern darussalam Gontor, Jurnal Nizham, Vol.4, No.02 JuliDesember 2015.

M. Ihsan Dacholfany, Konsep Masyarakat Madani Dalam Islam, Jurnal Akademika, 2012.

Makdisi, George A. Cita Humanisme Islam. terj. A. Syamsu Rizal dan Nur Hidayah. Jakarta: PT Ikrar Mandiri Abadi, 2005.

Muthahhari, Murtadha. Pengantar Epistemologi Islam. terj. Muhammad Jawad Bafaqih. Jakarta: Sadra Press, 2010.

Nata, Abuddin. Pemikiran Para Tokoh Pendidikan Islam. Jakarta: Raja Grafindo Persada, 2000. 
Rahman, Fazlur. Tema-Tema Pokok Al Qur'an. Bandung: Pustaka, 2000.

Ridla, Muhammad Jawwad. Tiga Aliran Utama Teori Pendidikan Islam. terj. Mahmud Arif. Yogyakarta: PT Tiara Wacana, 2002.

Seyyed Hossein Nasr dkk. Ensiklopedi Tematis Filsafat Islam. Bandung: Mizan, 2003.

Soleh, A. Khudori. Wacana Baru Filsafat Islam. Yogyakarta: Pustaka Pelajar, 2012.

Stanton, Charles Michael. Pendidikan Tinggi Dalam Islam. ter. Afandi, Hasan Asari. Jakarta: Logos Publishing House, 1994.

Syamsul Arifin, dkk. Spiritualisasi Islam Dan Peradaban Masa Depan. Yogyakarta: Sipres, 1996.

Tim Penyusun. Ensiklopedia Islam. 4. Jakarta: Van Hoeve Letiar Baru, 1997. 